\title{
UTE MRI of the Osteochondral Junction
}

\author{
Won C. Bae $\cdot$ Reni Biswas $\cdot$ Karen Chen \\ Eric Y. Chang $\cdot$ Christine B. Chung
}

Published online: 24 December 2013

(C) Springer Science+Business Media New York 2013

\begin{abstract}
The osteochondral junction is composed of numerous tissue components and serves important functions relating to structural stability and proper nutrition in joints such as the knee and spine. Conventional MR techniques have been inadequate at imaging the tissues of the osteochondral junction primarily because of the intrinsically short $\mathrm{T} 2$ nature of these tissues, rendering them "invisible" with the standard acquisitions. Ultrashort time to echo (UTE) MR techniques acquire sufficient MR signal of osteochondral tissues, thereby allowing direct evaluation. This article reviews the anatomy of the osteochondral junction of the knee and the spine, technical aspects of UTE MRI, and the application of UTE MRI for evaluation of the osteochondral junction.
\end{abstract}

Keywords Magnetic resonance imaging .

Musculoskeletal $\cdot$ Knee $\cdot$ Cartilage $\cdot$ Spine $\cdot$ Endplate

This article is part of the Topical Collection on Cartilage Imaging.

W. C. Bae $(\bowtie) \cdot$ R. Biswas $\cdot$ K. Chen ·

E. Y. Chang $\cdot$ C. B. Chung

Department of Radiology, University of California, San Diego,

408 Dickinson St., San Diego, CA 92103-8226, USA

e-mail:wbae@ucsd.edu

R. Biswas

e-mail: biswas.reni@gmail.com

K. Chen

e-mail: karenchanchen@gmail.com

E. Y. Chang

e-mail: ericchangmd@gmail.com

C. B. Chung

e-mail: cbchung@ucsd.edu

W. C. Bae - K. Chen - E. Y. Chang - C. B. Chung

VA San Diego Healthcare System, 3350 La Jolla Village Drive MC-114, San Diego, CA 92161, USA

\section{Introduction: Osteochondral Junction}

The osteochondral junction predominates in many joints in the human body where cartilage attaches to the subchondral bone. These include diarthrodial joints such as the knee and the hip as well as fibrocartilaginous joints such as the intervertebral discs. The anatomy of the osteochondral junction is complex, as several tissue components exist near the junction. For example, in a vertical cross section of the femoral condyle, layers of tissues (Fig. 1a) including uncalcified cartilage (which has superficial, middle and deep layers [1]), calcified cartilage and subchondral bone are present. Similarly, in the spine, layers of tissues (Fig. 1b) including the disc proper (nucleus pulposus and/ or annulus fibrosus), uncalcified and calcified cartilaginous endplates, and subchondral bone of vertebral endplate exist. The term "osteochondral junction" is rather loosely defined and may refer to one or more tissue components in the region.

In the knee, the osteochondral junction (Fig. 1a) serves to connect the overlying articular cartilage to the subchondral bone via calcified cartilage. The deepest layer of softer uncalcified cartilage has radially oriented collagen fibrils [1] that embed into much stiffer calcified cartilage at the tidemark or the calcification front. Calcified cartilage interdigitates with the subchondral bone, and the rough interface between the tissues combined with high stiffness [2] of the calcified cartilage provides mechanical stability and resistance against shear failure [3]. Calcified cartilage is a thin (100-200 $\mu \mathrm{m}$ thick [4•]) tissue, is metabolically active [5], consists of a large proportion of hydroxyapatite ( $\sim 65 \%$ [6]), and remodels with loading [7] and aging [8]. Lane et al. [4•] has showed that calcified cartilage thickness decreases with age, from $\sim 200 \mu \mathrm{m}$ at about age 20, down to less than $100 \mu \mathrm{m}$ by age 90 . Subchondral bone consists 


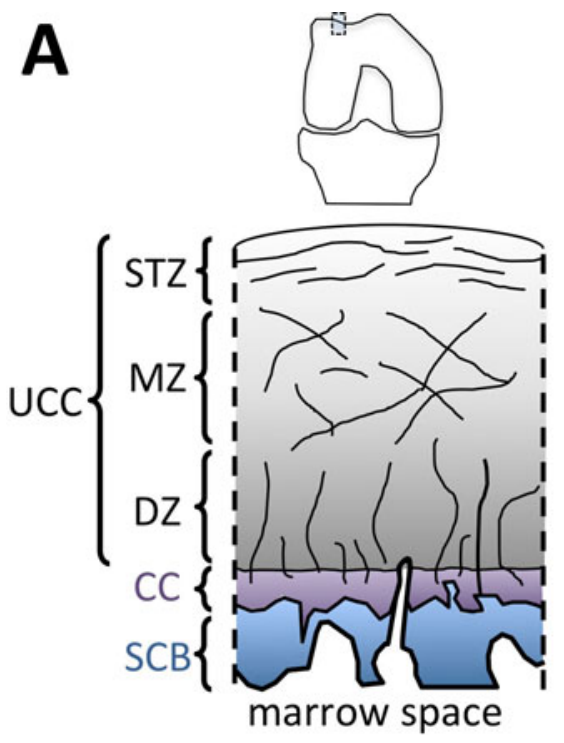

Fig. 1 Anatomy. a Osteochondral junction of the knee. Uncalcified articular cartilage (UCC) consists of three layers: the superficial tangential zone (STZ), middle zone (MZ) and deep zone (DZ). The UCC is attached to the subchondral bone (SCB) via calcified cartilage (CC), which interdigitates with subchondral bone and forms a tight junction. There are vascular canals penetrating the SCB and CC, which allow diffusion of solutes between the deep zone cartilage and

mostly of impermeable cortical bone and provides underlying support for uncalcified and calcified cartilage. The thickness of the subchondral bone plate is on the order of $2 \mathrm{~mm}$, but varies with location, age and joint degeneration [9]. Vascular canals penetrate both the subchondral bone and calcified cartilage, providing a nutritional pathway between the bone marrow and articular cartilage.

The osteochondral junction of the knee has been implicated in the pathogenesis of osteoarthritis. In addition to age-related changes in calcified cartilage [4•], joint loading can induce injury or degenerative changes at the osteochondral junction, including subarticular fracture [10], cloning of the cell in the calcified cartilage layer [11] and cell death in the deep layer [12]. It is also important for cartilage repair. During microfracture surgery in animals, the presence of the calcified cartilage layer is an important determinant of the outcome of the surgery [13].

A similar structure is also seen at the disco-vertebral junction (Fig. 1b) of the spine. Here, the nucleus pulposus and annulus fibrosus anchor into the uncalcified cartilaginous endplate (CEP), which is attached to the calcified CEP, supported by the subchondral bone. The uncalcified CEP is $\sim 1 \mathrm{~mm}$ thick, and its extracellular matrix consists mainly of proteoglycans, collagen and water. Calcified CEP is $\sim 100 \mu \mathrm{m}$ thick and interdigitates with the subchondral bone, similar to the calcified cartilage of the knee. The detailed collagen network architecture of this region has been documented by Inoue et al. [14•] and Wade et al. [15•].
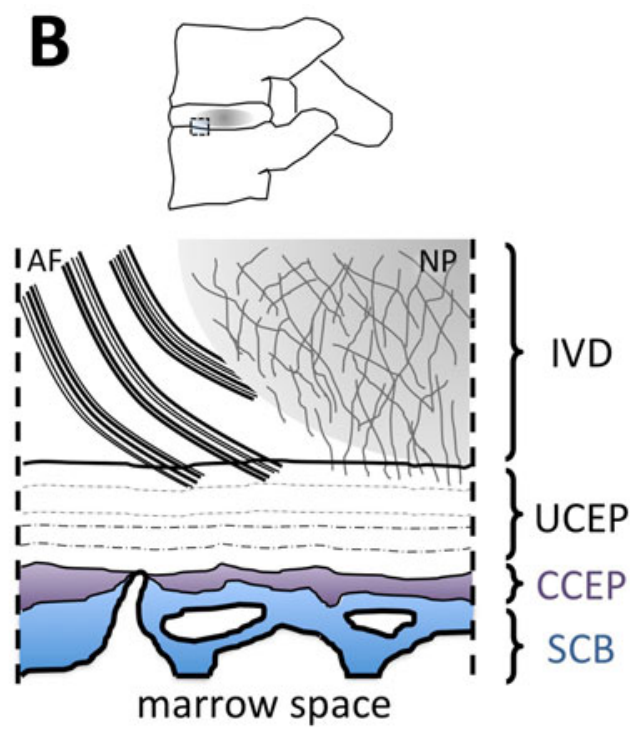

the marrow space. b Osteochondral junction of the spine or discovertebral junction. Components of the intervertebral disc (IVD) including the annulus fibrosus (AF) and nucleus pulposus (NP) anchor into the uncalcified cartilaginous endplate (UCEP), which is attached to the calcified cartilaginous endplate (CCEP), supported by the subchondral bone (SCB)

Due to avascular nature, the intervertebral discs must receive a large proportion of nutrition via disco-vertebral junction. A rich supply of blood vessels exists [16], penetrating the subchondral bone and the calcified CEP. Studies have shown a correlation between the low density of vascular canals with disc degeneration [17], emphasizing a nutritional role of the disco-vertebral junction and implication for disc degeneration. Other age-related changes in the CEP have been suggested, such as thinning and occlusion of vascular canals by ectopic calcification [18]. A non-invasive and sensitive method to detect changes in the osteochondral junctions of the human joints would be of considerable value for early diagnosis and understanding of the pathogenesis.

\section{Limitation of Conventional MRI and Advantage of UTE MRI}

While the importance of the osteochondral junction for proper function and degeneration of human joints has been recognized, it has been difficult to evaluate this important region using conventional magnetic resonance imaging (MRI) techniques. Tissues of the human body have intrinsic MR properties, such as T1 (spin-lattice relaxation time constant), T2 (spin-spin relaxation time constant) and T1rho (spin-lattice relaxation time constant in rotating frame) [19]. MR pulse sequences, by adjusting parameters 

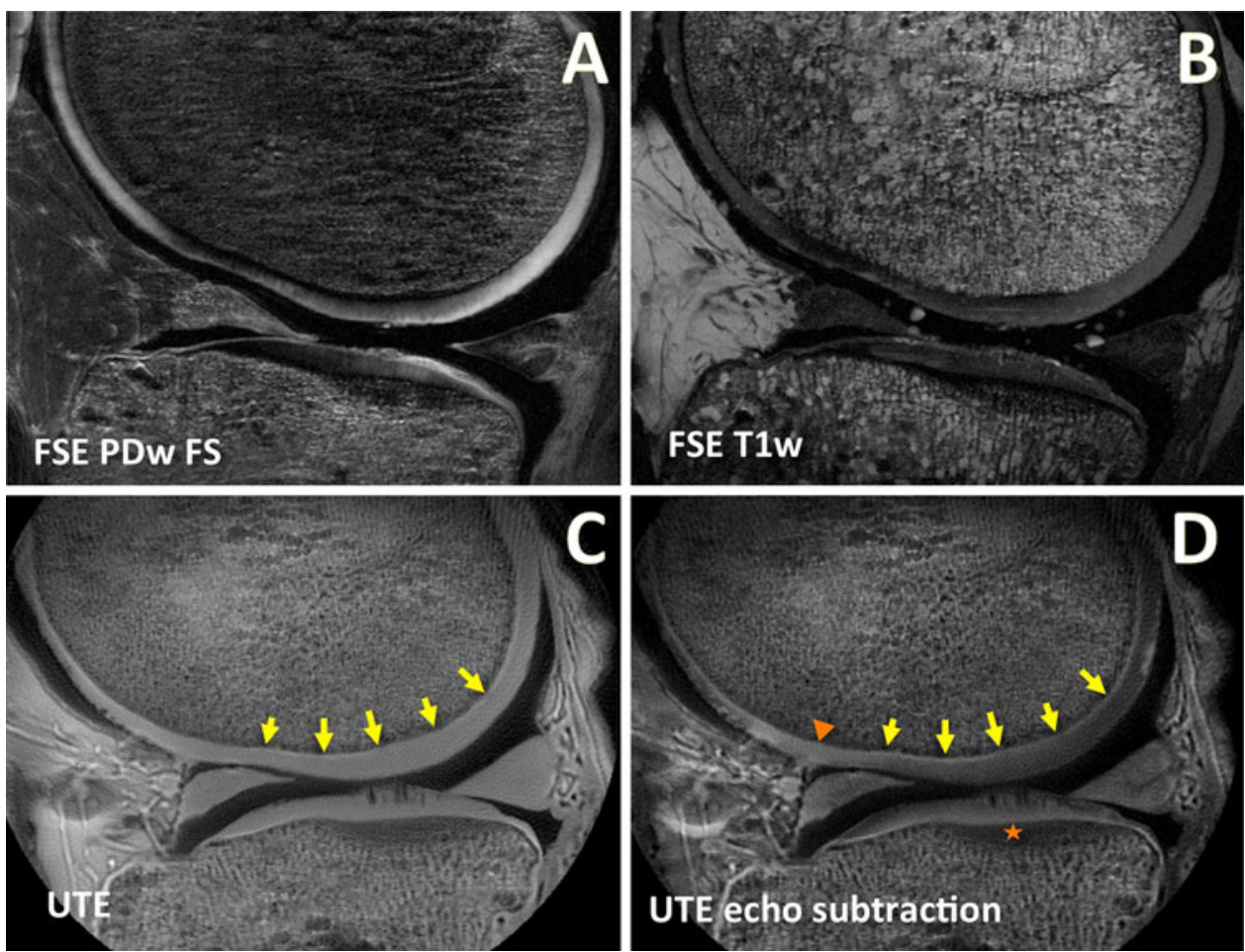

Fig. 2 MR images of a human knee in the sagittal plane obtained using conventional and UTE techniques. Conventional fast spin echo (FSE) a proton density-weighted fat suppressed (PDw FS; $\mathrm{TR}=2,000 \mathrm{~ms}, \quad \mathrm{TE}=30 \mathrm{~ms}) \quad$ and $\quad$ b $\mathrm{T} 1$-weighted $\quad(\mathrm{T} 1 \mathrm{w}$; $\mathrm{TR}=500 \mathrm{~ms}$, TE $=15 \mathrm{~ms}$ ) MR images are often used for clinical evaluation. These conventional MR images exhibit low signal intensity at the osteochondral junction and are more susceptible to magic angle effects. $\mathbf{c}$ UTE MR image obtained at TR $=300 \mathrm{~ms}$ and $\mathrm{TE}=0.008 \mathrm{~ms}$ exhibit many soft tissues with high signal intensity,

of time to repeat (TR), time to echo (TE) and time to spin lock (TSL), are able to obtain images depicting many structures of the joint with preferred contrast. For example, Fig. 2a and $b$ shows images of a knee, showing articular cartilage with different signal intensities relative to the surrounding tissues.

However, due to technical limitations of clinical MR scanners, many tissues have remained "invisible" (i.e., have very low signal intensity) on conventional MR images. A primary reason for this is the intrinsic $\mathrm{T} 2$ or $\mathrm{T} 2 *$ of the tissue being too short to provide a detectable signal when imaged with a conventional sequence with relatively long TE (e.g., Fig. 2a, b). In the knee, the bulk of articular cartilage has intermediate T2 values of $\sim 50 \mathrm{~ms}$ (Fig. 3a), while the layer of calcified cartilage has $\mathrm{T} 2$ value $\sim 2 \mathrm{~ms}$ [20]. Similarly, the nucleus pulposus of the intervertebral disc has a long T2 value $\sim 150 \mathrm{~ms}$, while both uncalcified and calcified CEPs have much shorter T2 values, less than $5 \mathrm{~ms}$ (Fig. 6). Subchondral bone has even shorter T2 values than $1 \mathrm{~ms}$ [21]. Given that a practical minimum TE is $\sim 10 \mathrm{~ms}$ for a spin echo sequence and $\sim 2 \mathrm{~ms}$ for a

including the osteochondral junction (arrows). In UTE images, the magic angle artifact in the articular cartilage is reduced compared to conventional MR images. d After subtracting the second echo image (at TE $=8 \mathrm{~ms}$ ) from the UTE image, the osteochondral junction is seen with much greater contrast due to suppression of longer T2 signals. In the subtraction image, osteochondral regions of abnormal morphology can be readily identified, including a region with signal loss (triangle) and another region with diffuse thickening (star)

gradient echo sequence, many short $\mathrm{T} 2$ tissues near the osteochondral junction will be "invisible" or imaged with suboptimal contrast because of the rapidly decaying MR signal.

Ultrashort TE (UTE) techniques allow acquisition of MR signals much earlier after excitation than with conventional sequences. With UTE sequences, the minimum TE can now be as short as $8 \mu$ s [21]. As a result, MR signal from previously "invisible" tissues with very short T2 values can now be acquired and imaged with high signal intensity (Figs. 2c, d and 4c, d). The majority of tissues near the osteochondral junction, including the deepest layer of the articular cartilage, calcified cartilage, and uncalcified and calcified CEP, can now be directly imaged using UTE techniques.

\section{UTE MR Techniques}

A number of UTE techniques have been developed and refined, focusing on the method of image acquisition, 

knee. Conventional a spin echo multi-echo T2 map (SE;

$\mathrm{TR}=2,000 \mathrm{~ms}$,

$\mathrm{TE}=10-80 \mathrm{~ms}, 8 \mathrm{TEs})$ and

b spiral chopped magnetization preparation (SCMP;

$\mathrm{TR}=1,500 \mathrm{~ms}, \mathrm{TE}=3 \mathrm{~ms}$,

$\mathrm{TSL}=10-40 \mathrm{~ms}, 4 \mathrm{TSLs}$ )

show relatively high $\mathrm{T} 2$ and

T1rho values of articular

cartilage. In comparison, quantitative c UTE T2*

(TR $=100 \mathrm{~ms}$,

$\mathrm{TE}=0.012-60 \mathrm{~ms}, 16 \mathrm{TEs})$

and d UTE T1rho

$(\mathrm{TR}=100 \mathrm{~ms}, \mathrm{TE}=0.012$,

$\mathrm{TSL}=0.02-10 \mathrm{~ms}, 4 \mathrm{TSLs})$

are able to detect short $\mathrm{T} 2$

components in articular cartilage and other soft tissues
Fig. 3 Quantitative MRI of the
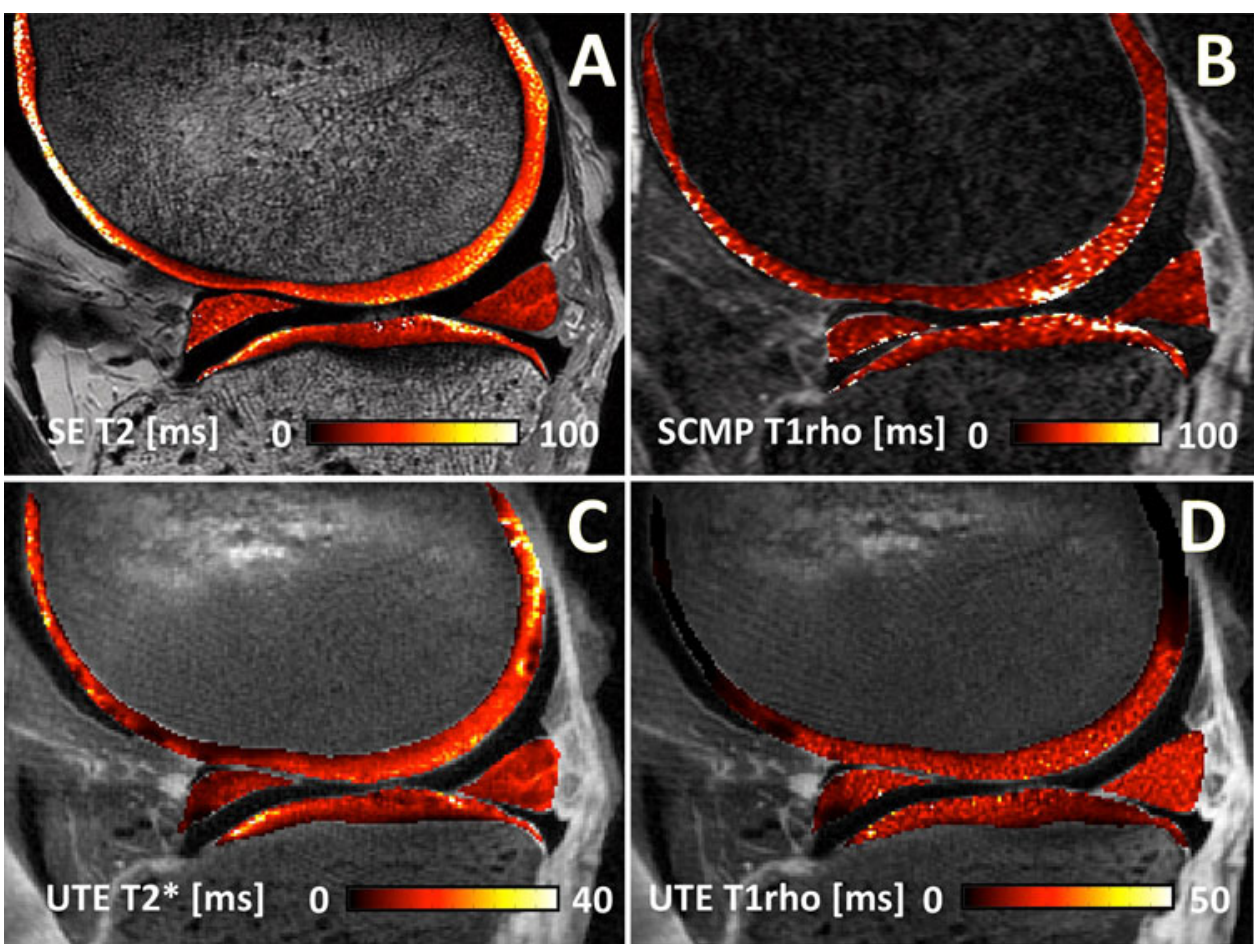

Fig. 4 Morphologic MRI of a human lumbar spine in the sagittal plane using conventional and UTE techniques. Conventional fast spin echo (FSE) a T2-weighted (T2w; TR $=2,000 \mathrm{~ms}$,

$\mathrm{TE}=80 \mathrm{~ms}$ ) and $\mathbf{b} \mathrm{T} 1$ weighted $(\mathrm{T} 1 \mathrm{w}$; TR $=600 \mathrm{~ms}$, $\mathrm{TE}=10 \mathrm{~ms}$ ) $\mathrm{MR}$ images are often used for clinical evaluation of the disc proper (square) and the bone marrow (circle). These conventional MR images exhibit low signal intensity at the disco-vertebral junction (arrows). c UTE MR images obtained at

$\mathrm{TR}=300 \mathrm{~ms}$ and

$\mathrm{TE}=0.01 \mathrm{~ms}$ reveal high signal intensity at the discovertebral junction (arrows) as well as the disc proper (square). d After subtracting the second echo image (at TE $=11 \mathrm{~ms}$ ) from the UTE image, the osteochondral junction is seen with a much greater contrast. A focal region of abnormal discovertebral junction (triangle) can now be seen
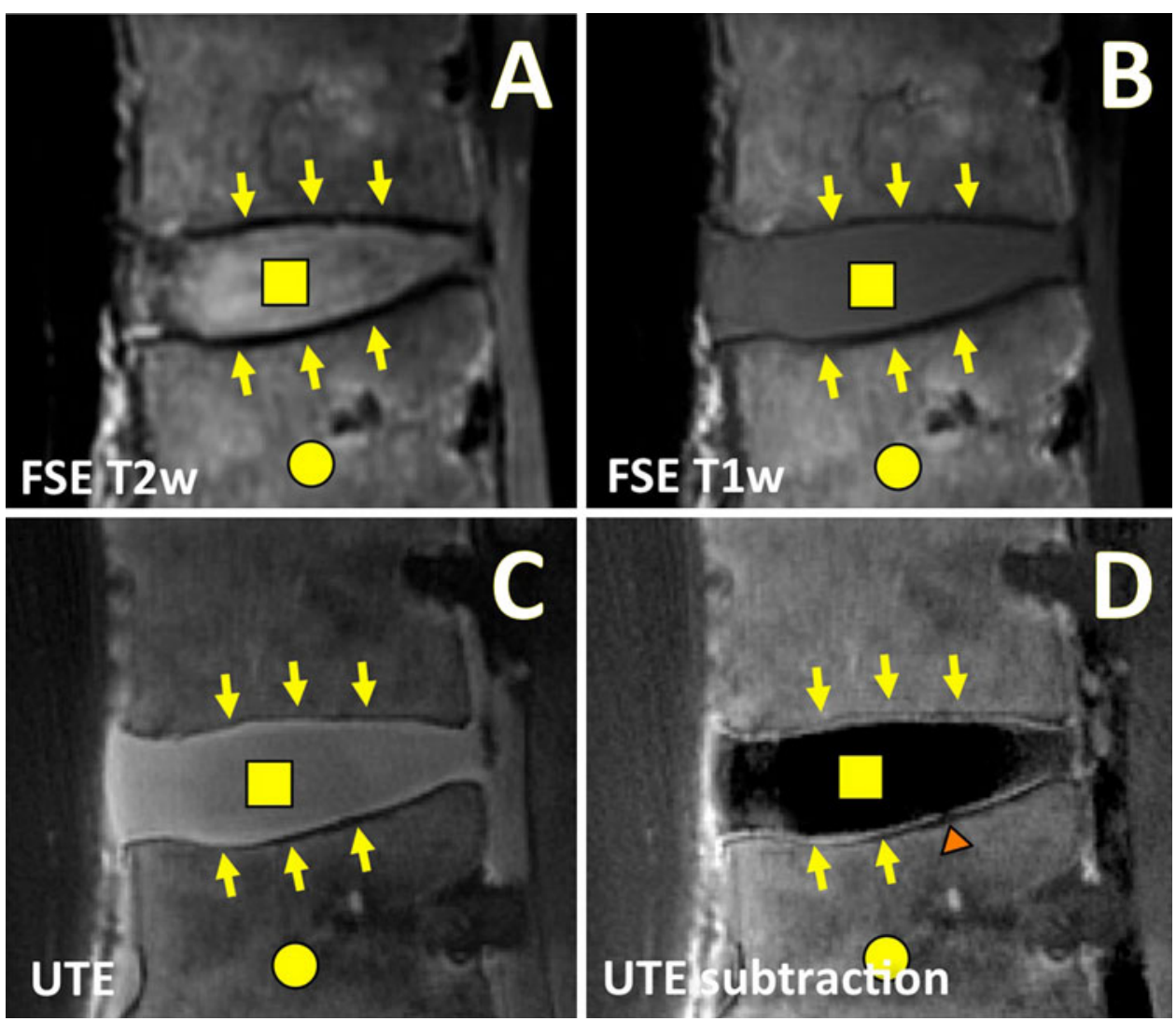

contrast enhancement, and quantitation of MR properties. Methods of image acquisition include two-dimensional (2D) [22-24] and three-dimensional (3D) [25, 26] approaches. The 2D UTE sequence typically employs half excitation pulses with radial sampling of k-space from the center out $[27,28]$. Data from the two half excitations are 
Table 1 Morphologic UTE MRI for evaluation of human musculoskeletal tissues

\begin{tabular}{|c|c|c|c|}
\hline Organ or tissue & Technique (Scan parameters) & Findings & Ref. \\
\hline Knee & $\begin{array}{l}\text { 3D UTE-weighted subtraction }(\mathrm{TR}=6 \mathrm{~ms}, \mathrm{TE}=0.07 \\
\text { and } 3.8 \mathrm{~ms} \text { ) }\end{array}$ & $\begin{array}{l}\text { Determined weighting factors optimized for cartilage, } \\
\text { tendon, bone, meniscus }\end{array}$ & [35] \\
\hline $\begin{array}{l}\text { Mandibular } \\
\text { condyle }\end{array}$ & $\begin{array}{l}\text { 3D UTE }(\mathrm{TR}=50 \mathrm{~ms}, \mathrm{UTE}=0.05 \mathrm{~ms} \\
\text { FOV }=4 \mathrm{~cm}, \text { matrix }=384 \times 384 \times 384)\end{array}$ & $\begin{array}{l}\text { Condylar fibrocartilage imaged with high signal intensity, } \\
\text { allowing determination of } 3 \mathrm{D} \text { contour }\end{array}$ & {$[78]$} \\
\hline $\begin{array}{l}\text { Disco-vertebral } \\
\text { junction }\end{array}$ & $\begin{array}{l}\text { 2D UTE subtraction }(\mathrm{TR}=300 \mathrm{~ms}, \mathrm{TE}=0.008 \text { and } \\
6.6 \mathrm{~ms})\end{array}$ & $\begin{array}{l}\text { Identified uncalcified and calcified cartilaginous endplates } \\
\text { as sources of high linear signal intensity }\end{array}$ & {$[74 \bullet \bullet]$} \\
\hline Lumbar spine & $3 \mathrm{D}$ UTE $(\mathrm{TR}=4.8 \mathrm{~ms}, \mathrm{TE}=0.14 \mathrm{~ms})$ & $\begin{array}{l}\text { Found association between the presence of CEP defects } \\
\text { and disc degeneration }\end{array}$ & [77] \\
\hline $\begin{array}{l}\text { Tibial cortical } \\
\text { bone }\end{array}$ & $\begin{array}{l}\text { 3D UTE: subtraction }(\mathrm{TR}=20 \mathrm{~ms}, \mathrm{TE}=0.06 \text { and } \\
4.6 \mathrm{~ms}) \text {, dual-band saturation }(\mathrm{TR}=240 \mathrm{~ms}) \\
\text { inversion recovery }(\mathrm{TR}=300 \mathrm{~ms}, \mathrm{TI}=100 \mathrm{~ms})\end{array}$ & $\begin{array}{l}\text { Subtraction and saturation techniques provided good short } \\
\text { T2 SNR and CNR. Inversion recovery had the lowest } \\
\text { SNR but uniform short T2 contrast }\end{array}$ & [79] \\
\hline Knee & $\begin{array}{l}\text { 2D UTE Spiral subtraction }(\text { Cor, } \mathrm{TR}=100 \mathrm{~ms}, \\
\mathrm{TE}=0.36 \mathrm{~ms}, 10 \mathrm{~ms})\end{array}$ & $\begin{array}{l}\text { In healthy subjects, deep layer of articular cartilage was } \\
\text { visualized }\end{array}$ & {$[80]$} \\
\hline Meniscus & $\begin{array}{l}\text { 3D UTE subtraction }(\mathrm{TR}=35 \mathrm{~ms}, \mathrm{TE}=0.056 \text {, } \\
5.1 \mathrm{~ms})\end{array}$ & Meniscal calcifications detected with high signal intensity & {$[61]$} \\
\hline Knee & $\begin{array}{l}\text { 3D AWSOS UTE }(\mathrm{TR}=80 \mathrm{~ms}, \mathrm{TE}=0.6-0.8 \mathrm{~ms} \text {, in- } \\
\text { plane voxel }=0.14 \mathrm{~mm})\end{array}$ & $\begin{array}{l}\text { Feasibility of high resolution UTE imaging using } \\
\text { AWSOS sequence }\end{array}$ & [81] \\
\hline $\begin{array}{l}\text { Lower leg, knee, } \\
\text { Achilles } \\
\text { tendon, } \\
\text { forearm }\end{array}$ & $\begin{array}{l}\text { 3D UTE subtraction, rescaled subtraction, long T2 } \\
\text { water and fat saturation, single inversion recovery, } \\
\text { double inversion recovery }\end{array}$ & $\begin{array}{l}\text { Feasibility shown for in vitro and in vivo imaging of } \\
\text { osteochondral junction, aponeuroses, meniscus, tendon, } \\
\text { ligament and cortical bone }\end{array}$ & {$[25]$} \\
\hline Tooth & 3D SWIFT $(\mathrm{TR}=2.5 \mathrm{~ms}, \mathrm{TE}=0.006 \mathrm{~ms})$ & Hard and soft tissues of teeth were simultaneously imaged & {$[82]$} \\
\hline $\begin{array}{l}\text { Wrist (cortical } \\
\text { bone) }\end{array}$ & WASPI & $\begin{array}{l}\text { WASPI technique allows imaging of solid bone matrix } \\
\text { and tendons, with suppression of soft tissues }\end{array}$ & [83] \\
\hline $\begin{array}{l}\text { Achilles tendon } \\
\text { and cortical } \\
\text { bone }\end{array}$ & $\begin{array}{l}\text { 2D UTE OSC and subtraction }(\mathrm{TR}=200-300 \mathrm{~ms} \text {, } \\
\text { TE }=0.008 \mathrm{~ms})\end{array}$ & $\begin{array}{l}\text { UTE-OSC technique suppresses long } \mathrm{T} 2 \text { water and fat } \\
\text { effectively, creating high contrast for short } \mathrm{T} 2 \text { tissues }\end{array}$ & [84] \\
\hline Foot, ankle, knee & $\begin{array}{l}\text { 3D UTE subtraction }(\mathrm{TR}=7.7 \mathrm{~ms}, \mathrm{TE}=0.05 \mathrm{~ms}, \\
2.3 \mathrm{~ms} \text { at } 3 \mathrm{~T}), 3 \mathrm{D} \text { UTE magnetization preparation } \\
\text { (long } \mathrm{T} 2 \text { and fat suppression) }\end{array}$ & Both techniques well suited for long T2 suppression & {$[32]$} \\
\hline $\begin{array}{l}\text { Tibial cortical } \\
\text { bone and ankle }\end{array}$ & $\begin{array}{l}\text { 2D UTE with inversion recovery pulse }(\mathrm{TR}=300 \mathrm{~ms} \text {, } \\
\mathrm{TE}=80 \mu \mathrm{s})\end{array}$ & $\begin{array}{l}\text { T2 suppression allows good visualization of bone and } \\
\text { tendon }\end{array}$ & {$[38]$} \\
\hline Achilles & $\begin{array}{l}\text { 2D UTE subtraction }(\mathrm{TR}=500 \mathrm{~ms} ; \mathrm{TE}=0.08,6.0, \\
11.1,17.7 \mathrm{~ms})\end{array}$ & $\begin{array}{l}\text { UTE MRI shows pathological changes and not seen in } \\
\text { conventional MRI }\end{array}$ & {$[63]$} \\
\hline Spine & $\begin{array}{l}\text { 2D UTE subtraction }(\mathrm{TR}=500 \mathrm{~ms}, \mathrm{TE}=0.08,6.0, \\
11.1,17.7 \mathrm{~ms})\end{array}$ & $\begin{array}{l}\text { UTE sequence shows hyper-intense band near } \\
\text { cartilaginous endplates }\end{array}$ & [85] \\
\hline Meniscus & $\begin{array}{l}\text { 2D UTE subtraction }(\mathrm{TR}=500 \mathrm{~ms}, \mathrm{TE}=0.08,6.0 \text {, } \\
11.1,17.7 \mathrm{~ms}) \text {, with and without contrast } \\
\text { administration }\end{array}$ & $\begin{array}{l}\text { Increase in SI of red zone and perimeniscal tissue after } \\
\text { contrast injection, especially at shorter TEs }\end{array}$ & [86] \\
\hline
\end{tabular}

$2 D$ Two dimensional, $3 D$ three dimensional, UTE ultrashort time to echo, IR inversion recovery, DIR dual inversion recovery, TR time to repeat, $T E$ time to echo, $T I$ time to invert, $F O V$ field of view, $S N R$ signal-to-noise ratio, $C N R$ contrast-to-noise ratio, $C E P$ cartilaginous endplate, $A W S O S$ acquisition weighted stack of spirals, SWIFT sweep imaging with Fourier transformation, WASPI water- and fat-suppressed proton projection MRI

subsequently combined to produce a single radial line of $\mathrm{k}$-space. The radial $\mathrm{k}$-space data are converted to a Cartesian grid and reconstructed by $2 \mathrm{D}$ inverse Fourier transformation (FT). The 3D UTE sequences usually employ a short hard pulse excitation followed by $3 \mathrm{D}$ radial ramp sampling [25, 26, 29] or 3D cones trajectory [30], followed by re-gridding of k-space onto a Cartesian grid and 3D inverse FT.

These image acquisition sequences may be used in conjunction with techniques to modulate image contrast. In particular, suppression of the long T2 signal while preserving the short $\mathrm{T} 2$ signal has been of interest in order to better evaluate short T2 tissues. A simple and effective technique is to acquire two images at varying echo times and perform digital image subtraction $[31 \cdot 32]$. The first echo image (obtained at the minimum TE, typically less than $0.1 \mathrm{~ms}$ ) contains MR signals from both short and long T2 tissues (Figs. 2c, 4c), while the second echo image (obtained at longer TEs, typically greater than a few $\mathrm{ms}$ ) contains the signal mainly from the long $\mathrm{T} 2$ tissues since 
the signal from the short $\mathrm{T} 2$ tissues has mostly decayed away. Subtracting the second image from the first image thus yields an image unmasking short T2 tissues (Figs. 2d, 4d). For this technique, short T2 contrast can be modulated by varying TEs, usually the later TE [33]. A variation of this technique, such as rescaled or weighted digital subtraction $[34,35]$, is also available. Other advanced techniques involving long $\mathrm{T} 2$ water saturation [36, 37] or inversion nulling of water [25,38] or water and fat using dual adiabatic inversion recovery (DIR) [39] have also been introduced. It should be noted that short $\mathrm{T} 2$ tissues often have short $\mathrm{T} 1$ values. For example, in the human spine, the $\mathrm{T} 1$ value of the nucleus pulposus is $\sim 1,250 \mathrm{~ms}$, while that of uncalcified CEP is $\sim 550 \mathrm{~ms}$ [40]. Such T1 differences can also be used to accentuate signal intensity from short $\mathrm{T} 2$ tissues by optimizing TR and the flip angle [40, 41]. Table 1 summarizes applications of morphologic UTE MRI for imaging of various musculoskeletal tissues.

UTE techniques also enable MR quantification of short T2 tissues. Quantitative techniques have been developed to determine UTE T2* and UTE T1rho values. T2* is typically determined by exponential fitting of UTE MR images obtained at different TEs [42, 43]. Similarly, UTE T1rho can be measured through exponential fitting of UTE T1rho images acquired at a series of spin-lock times (TSLs) [44]. Figure $3 \mathrm{c}$ and $\mathrm{d}$ shows UTE T2* and UTE T1rho maps of a knee slice, respectively. With a sufficient number of images, it is also possible to simultaneously determine short and long T2* components. UTE bicomponent analysis [45] utilizes a model that has a reduced number of fitting parameters and noise correction to determine both the value and fraction of short and long T2* components. An increasing number of studies seek to determine multicomponent $\mathrm{T} 2 *$ properties for musculoskeletal tissues [46, 47]. Table 2 summarizes the application of quantitative UTE MRI for imaging of various musculoskeletal tissues.

\section{UTE MR Evaluation of the Osteochondral Junction of the Knee}

Conventional MRI is routinely used to evaluate injury and repair of the articular cartilage of the knee [48-51]. Sequences such as fat-suppressed proton density-weighted

Table 2 Quantitative UTE MRI for evaluation of musculoskeletal tissues

\begin{tabular}{|c|c|c|c|}
\hline Organ or tissue & Technique (scan parameters) & Findings & Ref. \\
\hline $\begin{array}{l}\text { Meniscus and } \\
\text { cartilage in } \\
\text { meniscal repair }\end{array}$ & 2D UTE T2* $(\mathrm{TR}=350 \mathrm{~ms}, \mathrm{TE}=0.3,6.3,12.5,18.7 \mathrm{~ms})$ & $\begin{array}{l}\text { Higher UTE T2* values in repaired menisci and } \\
\text { articular cartilage. }\end{array}$ & [60] \\
\hline $\begin{array}{l}\text { Patella: zone of } \\
\text { calcified } \\
\text { cartilage (ZCC) }\end{array}$ & $\begin{array}{l}\text { 2D DIR UTE T2 } *(\mathrm{TR}=300 \mathrm{~ms}, \mathrm{TI} 1=140 \mathrm{~ms} \\
\text { TI } 2=105 \mathrm{~ms}, \mathrm{TE}=0.008-12 \mathrm{~ms}) ; 2 \mathrm{D} \text { DIR UTE T1rho } \\
(\mathrm{TSL}=0.02-12 \mathrm{~ms})\end{array}$ & $\begin{array}{l}\text { Characterization of patellar ZCC } \\
\text { UTE T2*: } 2.0 \pm 1.2 \mathrm{~ms} \\
\text { UTE T1rho: } 3.6 \pm 1.2 \mathrm{~ms}\end{array}$ & [87] \\
\hline $\begin{array}{l}\text { Meniscus } \\
\text { calcification }\end{array}$ & $\begin{array}{l}\text { 2D IR UTE T2* }(\mathrm{TR}=300 \mathrm{~ms}, \mathrm{TE}=0.012,0.05,0.1,0.2 \\
0.4 \mathrm{~ms}) ; 3 \mathrm{D} \text { UTE T2* }(\mathrm{TR}=35 \mathrm{~ms}, \mathrm{TE}=0.056,2,5.1 \\
7.1 \mathrm{~ms})\end{array}$ & $\begin{array}{l}\text { Lower T2* value of calcification }(\sim 10 \mathrm{~ms}) \\
\text { compared to surrounding tissue }(15-30 \mathrm{~ms})\end{array}$ & [61] \\
\hline Meniscus & $\begin{array}{l}\text { 3D AWSOS UTE T2* }(\mathrm{TR}=30 \mathrm{~ms}, \mathrm{TE}=0.6-40 \mathrm{~ms}, 11 \\
\text { TEs })\end{array}$ & $\begin{array}{l}\text { Meniscal T2* values were higher in ACL-injured } \\
\text { subjects, with and without concomitant tear }\end{array}$ & {$[62]$} \\
\hline $\begin{array}{l}\text { Cortical bone } \\
\text { (lower } \\
\text { extremity) }\end{array}$ & $\begin{array}{l}\text { 2D UTE T2* bicomponent analysis for short and long T2* } \\
\text { and fractions (TR }=200 \mathrm{~ms}, \mathrm{TE}=0.008-8 \mathrm{~ms}, 16 \mathrm{TEs} \text { ); } \\
\text { 3D UTE for total water content }\end{array}$ & $\begin{array}{l}\text { UTE measures of water content and } \mathrm{T} 2 * \text { fraction } \\
\text { correlated with porosity and biomechanical } \\
\text { measures of cortical bone }\end{array}$ & {$[55]$} \\
\hline $\begin{array}{l}\text { Knee articular } \\
\text { cartilage }\end{array}$ & $\begin{array}{l}\text { 3D AWSOS UTE T2* }(\mathrm{TR}=80 \mathrm{~ms}, \mathrm{TE}=0.6-40 \mathrm{~ms}, 11 \\
\text { TEs })\end{array}$ & $\begin{array}{l}\text { Repeatability of UTE T2* values of cartilage in } \\
\text { asymptomatic subjects was determined }\end{array}$ & [43] \\
\hline $\begin{array}{l}\text { Cortical bone } \\
\text { (lower } \\
\text { extremity) }\end{array}$ & $\begin{array}{l}\text { 3D hybrid-radial UTE T2* }(\mathrm{TR}=20 \mathrm{~ms}, 0.25-1.65 \mathrm{~ms}, 8 \\
\text { TEs) }\end{array}$ & Repeatable bone water quantification in vivo & {$[64]$} \\
\hline TMJ disc & 2D UTE T2 $*(\mathrm{TR}=500 \mathrm{~ms}, \mathrm{TE}=0.1-15 \mathrm{~ms}, 8 \mathrm{TEs})$ & $\begin{array}{l}\text { Significant correlation between UTE T2* and } \\
\text { indentation stiffness of TMJ disc was found }\end{array}$ & {$[88]$} \\
\hline Achilles & $\begin{array}{l}\text { 2D UTE T1rho }(\mathrm{TR}=400 \mathrm{~ms}, \mathrm{TE}=0.008 \mathrm{~ms}, \mathrm{TSL}=0.2 \text {, } \\
2,5,10 \mathrm{~ms})\end{array}$ & $\begin{array}{l}\text { UTE T1rho ranged from } 3.0 \pm 0.5 \mathrm{~ms} \text { for healthy } \\
\text { volunteers to } 5.2 \pm 0.6 \mathrm{~ms} \text { for specimens }\end{array}$ & {$[44]$} \\
\hline Meniscus & $\begin{array}{l}\text { 2D UTE T1rho }(\mathrm{TR}=400 \mathrm{~ms}, \mathrm{TE}=0.008 \mathrm{~ms}, \mathrm{TSL}=0.2 \text {, } \\
2,5,10 \mathrm{~ms})\end{array}$ & $\begin{array}{l}\text { UTE T1rho of } 7.98 \pm 1.43 \mathrm{~ms} \text { found in healthy } \\
\text { volunteers }\end{array}$ & [44] \\
\hline Achilles & 2D UTE $($ TR $=500 \mathrm{~ms}$, TEs $=0.14-2.5 \mathrm{~ms}, 8 \mathrm{TEs})$ & UTE T2* values of 2.9 and $3.0 \mathrm{~ms}$ were found & {$[63]$} \\
\hline
\end{tabular}

$2 D$ two dimensional, $3 D$ three dimensional, UTE ultrashort time to echo, $I R$ inversion recovery, $D I R$ dual inversion recovery, $T R$ time to repeat, $T E$ time to echo, $T I$ time to invert, FOV field of view, AWSOS acquisition-weighted stack of spirals, TMJ temporomandibular joint 
(PDw; long TR and short TE) (Fig. 2a) and T1-weighted (T1w; short TR and short TE) (Fig. 2b) spin echo or fast spin echo sequences are used to evaluate morphologic changes in articular cartilage as well as trabecular bone and bone marrow. However, tissues near the osteochondral junction are seen with low signal intensity in these conventional MR images. Additionally, the magic angle effect $[52,53]$ results in orientation-dependent fluctuations in signal intensity of the overlying cartilage, which further confounds evaluation of the osteochondral junction.

In contrast to conventional MR images, UTE MRI of the articular cartilage enables direct visualization of deep layers. Using the shortest TE of $0.008 \mathrm{~ms}$ (Fig. 2c), UTE MRI of a knee exhibits high signal intensity from all layers of the articular cartilage, meniscus, and surrounding connective tissues. In addition, it is apparent that the UTE MR image is less sensitive to the magic angle effect; similar signal intensity of articular cartilage is seen throughout the femoral condyle. In the image, the morphology of the osteochondral junction (Fig. 2c, arrows) is not well defined because of the confounding signal intensity from longer T2 tissues. After digital image subtraction of the second echo image (obtained at $\mathrm{TE}=8 \mathrm{~ms}$ ) to suppress long $\mathrm{T} 2$ signals, the resulting image (Fig. 2d) accentuates the signal intensity from short T2 tissues. Specifically, the osteochondral junction is seen with distinct, continuous and high signal intensity (Fig. 2d, arrows). In some samples, focal regions of abnormal morphology can be found, including thinning/absence of the signal intensity (Fig. 2d, triangle) or diffuse thickening (Fig. 2d, star). In a recent study performed on cadaveric patellae [54•], $\sim 80 \%$ of the combined length of all osteochondral junctions had a normal morphology, 10\% had thinned/absent morphology and the remainder had a thick diffuse morphology.

It remains to be determined how different UTE MR morphologies and properties are related to the structure and health of the osteochondral junction as well as other tissues of the knee. In an early validation study [54•], UTE MR morphology of experimentally prepared samples containing variable tissue components were compared. The following samples were prepared: intact osteochondral (uncalcified cartilage, calcified cartilage, subchondral bone), uncalcified cartilage, calcified cartilage and subchondral bone, and subchondral bone. Only the samples containing the uncalcified cartilage (at the deepest layer) and calcified cartilage exhibited the characteristic high linear signal intensity, suggesting those two tissue components are sources of the signal intensity. It should be noted that while the cortical bone is detectable using UTE techniques [55-57] when imaged on its own, when imaged alongside other short T2 tissues such as calcified cartilage, the subchondral bone exhibits a relatively low signal intensity. In another preliminary study [58], the UTE MR morphology of the osteochondral junction of the human patella was compared with histological measures of calcified cartilage thickness and roughness. Regions that exhibited the MR appearance of thinning or absence of the linear signal intensity had a thinner calcified cartilage as well as a smoother interface to the subchondral bone.

Quantitatively, UTE MRI has often been performed to evaluate full thickness articular cartilage or other tissues of the knee as a whole, but not specifically to evaluate the osteochondral junction. This is partly due to the thinness of the osteochondral junction of the knee, combined with the long scan duration required for achieving high spatial resolution in quantitative sequences. In a few in vitro studies that have evaluated UTE MR properties of the patellar osteochondral junction, UTE T1 values ranging from 250 to $400 \mathrm{~ms}$, UTE T2* values ranging from 1 to $3 \mathrm{~ms}$ and UTE T1rho values ranging from 2 to $5 \mathrm{~ms}$ were found in cadaveric patellar samples [20]. When UTE T2* and UTE T1rho values of the osteochondral junctions with normal versus abnormal UTE morphology were compared [59], abnormal regions with diminished signal intensity in subtraction images also had $\sim 40 \%$ greater UTE T2 $*$ and T1rho values than the normal regions. Quantitative UTE MR techniques are increasingly used to evaluate other parts of the lower extremities, including the overlying articular cartilage [43, 60], the meniscus [44, 61, 62], the ligaments [44, 63] and the cortical bone [55, 64]. Additional studies are needed to fully understand implications of MR changes of the osteochondral junction for the health of the knee.

\section{UTE MR Evaluation of the Osteochondral Junction of the Spine}

Conventional MRI is routinely used to evaluate intervertebral disc degeneration and associated conditions. Based on the MR signal intensity and morphology, disc grading $[65,66]$ can be performed, usually based on spin echo images in the sagittal plane (Fig. 4a, b). Conditions such as disc herniation and nerve root compression can be detected accurately $[67,68]$ using similar techniques. Conventional quantitative techniques have also been useful for evaluation of disc degeneration: T2 values of the disc correlate strongly with the water content $[69,70]$ and proteoglycan content $[71,72]$. Similar relations were found using T1rho imaging [73]. While useful for evaluation of the nucleus pulposus and anulus fibrosus, and gross morphology of the spine, conventional sequences yield very little signal from the region of the disco-vertebral junction (Fig. 4a, b, arrows). It should be noted that while it is feasible to image uncalcified CEP using conventional gradient echo imaging at a short TE [40], the image contrast for the CEP may be suboptimal. 

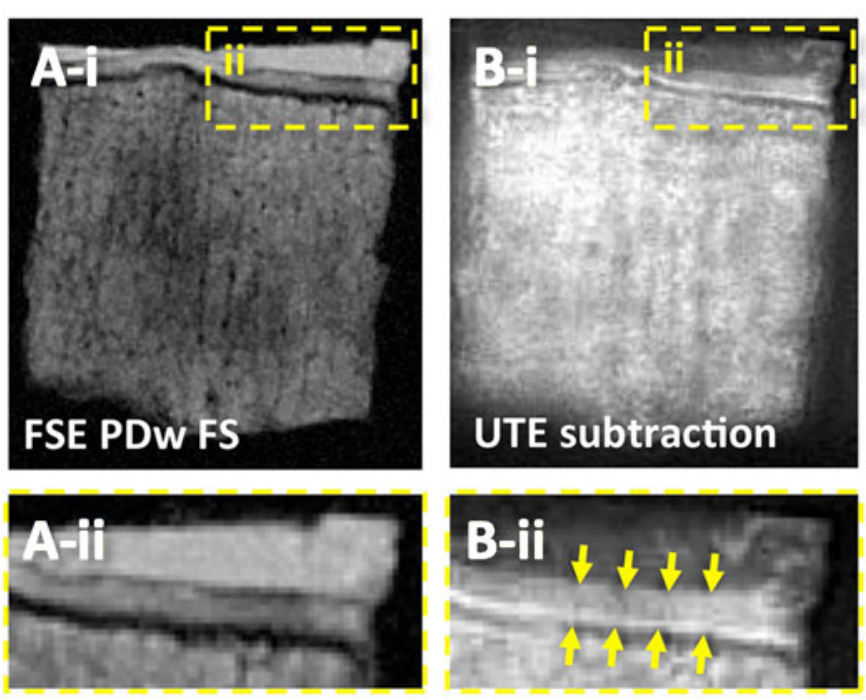

Fig. 5 Comparison of MRI and histology of a small disco-vertebral specimen. a Conventional fast spin echo proton density-weighted fatsuppressed (FSE PDw FS; TR $=2,000 \mathrm{~ms}$, TE $=15 \mathrm{~ms}$ ) image exhibits a medium to low signal intensity at the disco-vertebral junction. In contrast, $\mathbf{b}$ the UTE subtraction $(\mathrm{TR}=300 \mathrm{~ms}$, $\mathrm{TE}=0.008$ and $6.6 \mathrm{~ms}$ ) MR image exhibits a medium to high signal intensity with a bilaminar appearance. On the UTE subtraction image, the thicker layer with medium signal intensity (b-ii, downward arrows) corresponded with the thicker layer of the uncalcified

Ultrashort time-to-echo (UTE) MR techniques have enabled direct imaging of the osteochondral junction of the spine or disco-vertebral junction. Similar to knee imaging, the UTE image of the spine at the shortest TE reveals the entire disc (Fig. 4c, square) as well as the CEP (Fig. 4c, arrows) with medium to high signal intensity. Using the subtraction technique, the longer $\mathrm{T} 2$ signals are diminished, and the osteochondral junction is seen with a characteristic continuous, linear, and high signal intensity (Fig. 4d, arrows). With enhanced contrast, focal regions of abnormal morphology are more easily detected (Fig. 4d, triangle), unlike in the first echo UTE image (Fig. 4c). Abnormal morphologies including signal loss (Fig. 4d, triangle), thickening or irregularity have been noted. A histologic validation study [74••] has been performed on small disco-vertebral specimens (Fig. 5) containing the disc, uncalcified and calcified CEPs, and subchondral bone. This study confirmed that the CEPs (uncalcified and calcified) exhibit lowered signal intensity in conventional fast spin echo MRI (Fig. 5a), while the UTE subtraction image revealed two layers of characteristic high signal intensity (Fig. 5b-ii), which corresponded with thicker uncalcified and thinner calcified layers of CEP. In the corresponding histology (Fig. 5c), the structure and arrangement of these tissues at the osteochondral junction can be seen. Using a different combination of prepared samples, the study [74.0] determined that both uncalcified and calcified CEP contributed to the characteristic UTE MR morphology, while the disc

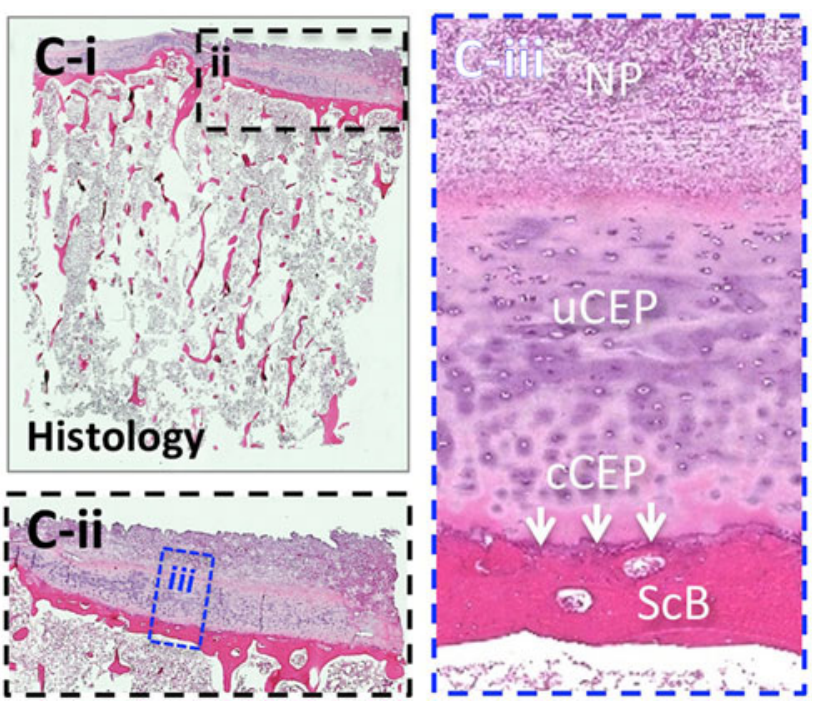

cartilaginous endplate, and a thinner layer (b-ii, upward arrows) of high signal intensity corresponded with the thinner layer of the calcified cartilaginous endplate. These observations were consistent with $\mathbf{c}$ the histology of the sample, stained with hematoxylin and eosin. In a through $\mathbf{c}$, $\mathbf{i}$ is the full-size image, and ii and iii are magnified images. NP nucleus pulposus, $u C E P$ uncalcified cartilaginous endplate, $c C E P$ calcified cartilaginous endplate, $S c B$ subchondral bone

tissue and subchondral bone did not. MR quantification of the disco-vertebral junction is also difficult because of the thinness of the region, but has been performed in a limited number of small specimens at a high spatial resolution (Fig. 6). Compared to a conventional multi-echo spin echo $\mathrm{T} 2$ sequence that yielded images (Fig. 6a-c) of the disco-vertebral junction with low signal intensity, both UTE T2* (Fig. 6f-h) and UTE T1rho (Fig. 6k-m) images show the region with high-to-medium signal intensity. The T2 map created from a conventional sequence (Fig. 6d) shows highly noisy results in the CEP, while the UTE T2* (Fig. 6i) and UTE T1rho (Fig. 6n) maps show smoother results, likely to be more accurate. Curve fitting (Fig. 6e, j, o) in the CEP region of interest suggested a UTE T2* value of $2.9 \mathrm{~ms}$ and a UTE T1rho value of $4.5 \mathrm{~ms}$ in the region.

Implications of the altered UTE MR morphology or MR properties of the disco-vertebral junction for spine health have yet to be determined. There is early evidence suggesting that abnormal UTE morphology is related to formation of calcium deposits in the CEP [75], determined by micro CT imaging. Such deposition may lead to occlusion of vascular canals and hindered nutrient transport into the disc. More importantly, in vitro [76] and in vivo [77] UTE MR studies have also shown that a significant association exists between abnormal UTE morphology and advanced degeneration of the adjacent discs. Increased UTE abnormality was also found with more aged subjects. Future UTE MRI studies may offer important insights 

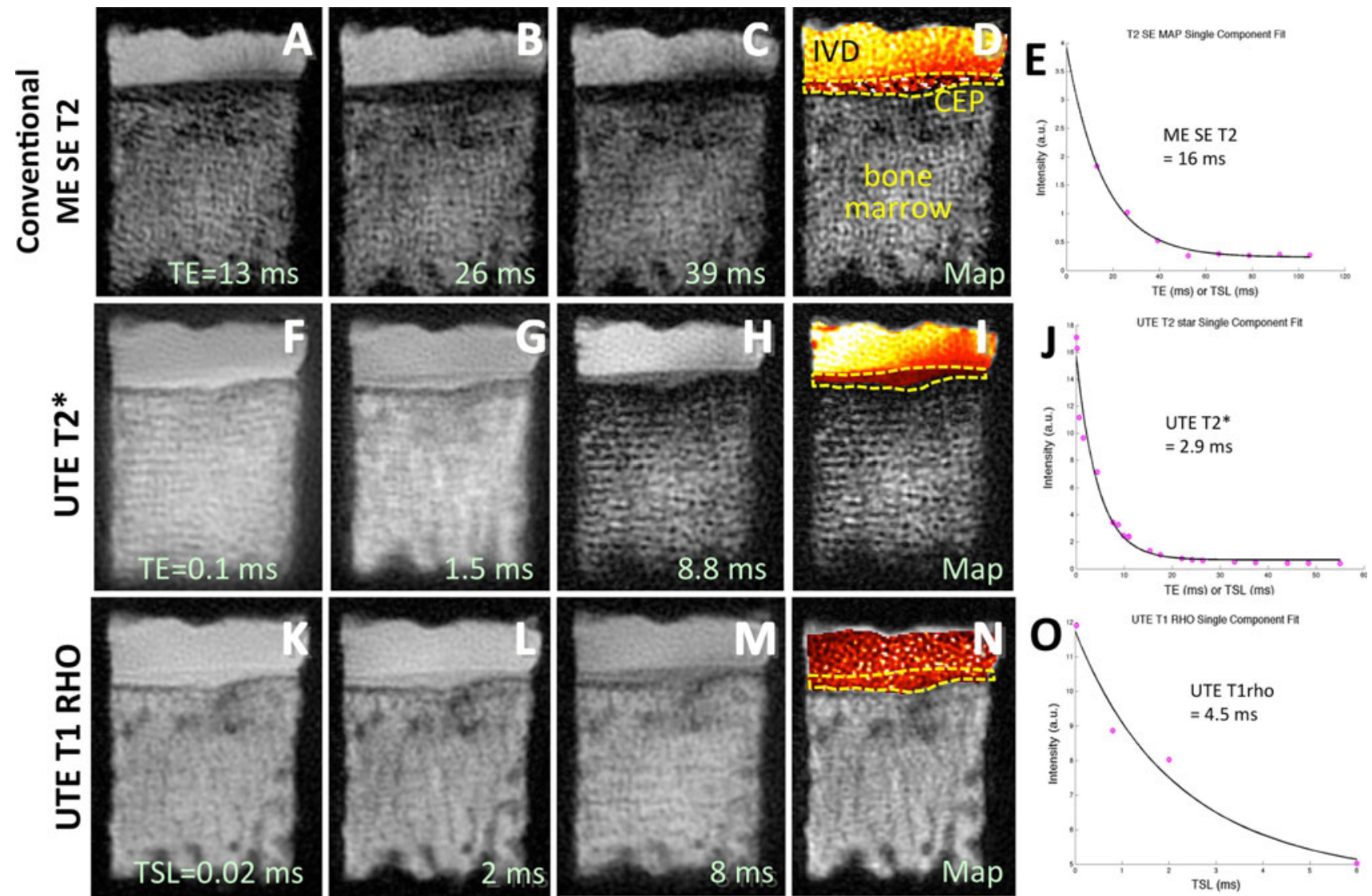

Fig. 6 Quantitative MRI of the disco-vertebral junction. a-c Conventional multi-echo spin echo T2 (ME SE T2) images taken at increasing TEs exhibit low signal intensity in the region of the cartilaginous endplate (CEP) (d, dotted line). $\mathbf{d}$ The resulting T2 map shows a lot of noise, and e the mean $\mathrm{T} 2$ value is relatively high at 16 ms. In contrast, $\mathbf{f}-\mathbf{h}$ UTE T2* and $\mathbf{k}-\mathbf{m}$ UTE T1rho images are

into the epidemiology of the pathology of the disco-vertebral junction and how it is related to spine health and back pain.

Acknowledgments We thank Ms. Sheronda Statum for preparation and scanning of knee samples and Drs. Koichi Masuda and Graeme Bydder for assistance with spine samples. This article was made possible in part by a grant from the National Institute of Arthritis and Musculoskeletal and Skin Diseases of the National Institutes of Health in support of Dr. Won C. Bae (Grant no. K01 AR059764) and a Veterans Affairs Merit grant in support of Dr. Christine B. Chung (project ID no. 1161961). The contents of this article are solely the responsibility of the authors and do not necessarily represent the official views of the National Institutes of Health or Veterans Affairs.

\section{Compliance with Ethics Guidelines}

Conflict of Interest Won C. Bae, Reni Biswas, Karen Chen, Eric Y. Chang and Christine B. Chung declare that they have no conflicts of interest.

Human and Animal Rights and Informed Consent This article does not contain any studies with human or animal subjects performed by the authors. able to depict the cartilaginous endplate with markedly higher signal intensity. Corresponding i UTE T2* and n UTE T1rho maps show consistent values throughout the CEP (dotted lines). $\mathbf{j}$ The mean UTE T2* and $\mathbf{o}$ mean UTE T1rho values of the CEP were 2.9 and $4.5 \mathrm{~ms}$, respectively

\section{References}

Papers of particular interest, published recently, have been highlighted as:

- Of importance

•- Of major importance

1. Buckwalter J, Hunziker E, Rosenberg L, Coutts R, Adams M, Eyre D. Articular cartilage: composition and structure. In: Woo SL-Y, Buckwalter JA, editors. Injury and repair of the musculoskeletal soft tissues. Park Ridge: American Academy of Orthopaedic Surgeons; 1988. p. 405-25.

2. Mente PL, Lewis JL. Elastic modulus of calcified cartilage is an order of magnitude less than that of subchondral bone. J Orthop Res. 1994;12:637-47.

3. St-Pierre JP, Gan L, Wang J, Pilliar RM, Grynpas MD, Kandel RA. The incorporation of a zone of calcified cartilage improves the interfacial shear strength between in vitro-formed cartilage and the underlying substrate. Acta Biomater. 2012;8:1603-15.

4. - Lane LB, Bullough PG. Age-related changes in the thickness of the calcified zone and the number of tidemarks in adult human articular cartilage. J Bone Joint Surg Br. 1980;62:372-5. This 
paper showed age-related changes in the structure of the osteochondral junction of the knee.

5. Green WT Jr, Martin GN, Eanes ED, Sokoloff L. Microradiographic study of the calcified layer of articular cartilage. Arch Pathol. 1970;90:151-8.

6. Zhang Y, Wang F, Tan H, Chen G, Guo L, Yang L. Analysis of the mineral composition of the human calcified cartilage zone. Int J Med Sci. 2012;9:353-60.

7. Oettmeier R, Arokoski J, Roth AJ, et al. Subchondral bone and articular cartilage responses to long distance running training (40 km per day) in the beagle knee joint. Eur J Musculoskelet Res. 1992;1:145-54.

8. Lane LB, Bullough PG. Age-related changes in the thickness of the calcified zone and the number of tidemarks in adult human articular cartilage. J Bone Joint Surg Br. 1980;62:372-5.

9. Yamada K, Healey R, Amiel D, Lotz M, Coutts R. Subchondral bone of the human knee joint in aging and osteoarthritis. Osteoarthr Cartil. 2002;10:360-9.

10. Atkinson PJ, Haut RC. Subfracture insult to the human cadaver patellofemoral joint produces occult injury. J Orthop Res. 1995;13:936-44.

11. Donohue JM, Buss D, Oegema TR, Thompson RC. The effects of indirect blunt trauma on adult canine articular cartilage. J Bone Joint Surg Am. 1983;65-A:948-57.

12. Milentijevic D, Torzilli PA. Influence of stress rate on water loss, matrix deformation and chondrocyte viability in impacted articular cartilage. J Biomech. 2005;38:493-502.

13. Frisbie DD, Morisset S, Ho CP, Rodkey WG, Steadman JR, McIlwraith CW. Effects of calcified cartilage on healing of chondral defects treated with microfracture in horses. Am J Sports Med. 2006;34:1824-31.

14. - Inoue H. Three-dimensional architecture of lumbar intervertebral discs. Spine 1981; 6:139-46. This paper provided detailed architecture of the disco-vertebral junction of the spine.

15. - Wade KR, Robertson PA, Broom ND. On the extent and nature of nucleus-annulus integration. Spine (Phila $\mathrm{Pa}$ 1976) 2012;37:1826-33. This paper provided the detailed architecture of the disco-vertebral junction of the spine.

16. Crock HV, Goldwasser M. Anatomic studies of the circulation in the region of the vertebral end-plate in adult Greyhound dogs. Spine (Phila Pa 1976). 1984;9:702-6.

17. Benneker LM, Heini PF, Alini M, Anderson SE, Ito K. 2004 young investigator award winner: vertebral endplate marrow contact channel occlusions and intervertebral disc degeneration. Spine. 2005;30:167-73.

18. Bernick S, Cailliet R. Vertebral end-plate changes with aging of human vertebrae. Spine (Phila Pa 1976). 1982;7:97-102.

19. Taylor C, Carballido-Gamio J, Majumdar S, Li X. Comparison of quantitative imaging of cartilage for osteoarthritis: T2, T1rho, dGEMRIC and contrast-enhanced computed tomography. Magn Reson Imaging. 2009;27:779-84.

20. Du J, Carl M, Bae WC, et al. Dual inversion recovery ultrashort echo time (DIR-UTE) imaging and quantification of the zone of calcified cartilage (ZCC). Osteoarthr Cartil. 2012;21:77-85.

21. Du J, Hamilton G, Takahashi A, Bydder M, Chung CB. Ultrashort echo time spectroscopic imaging (UTESI) of cortical bone. Magn Reson Med. 2007;58:1001-9.

22. Du J, Bydder M, Takahashi AM, Chung CB. Two-dimensional ultrashort echo time imaging using a spiral trajectory. Magn Reson Imaging. 2008;26:304-12.

23. Qian Y, Boada FE. Acquisition-weighted stack of spirals for fast high-resolution three-dimensional ultra-short echo time MR imaging. Magn Reson Med. 2008;60:135-45.

24. Idiyatullin D, Corum C, Park JY, Garwood M. Fast and quiet MRI using a swept radiofrequency. J Magn Reson. 2006;181:342-9.
25. Du J, Bydder M, Takahashi AM, Carl M, Chung CB, Bydder GM. Short T2 contrast with three-dimensional ultrashort echo time imaging. Magn Reson Imaging. 2011;29:470-82.

26. Rahmer J, Bornert P, Groen J, Bos C. Three-dimensional radial ultrashort echo-time imaging with T2 adapted sampling. Magn Reson Med. 2006;55:1075-82.

27. Young IR, Bydder GM. Magnetic resonance: new approaches to imaging of the musculoskeletal system. Physiol Meas. 2003;24:R1-23.

28. Gatehouse PD, Thomas RW, Robson MD, Hamilton G, Herlihy AH, Bydder GM. Magnetic resonance imaging of the knee with ultrashort TE pulse sequences. Magn Reson Imaging. 2004;22:1061-7.

29. Wu Y, Ackerman JL, Chesler DA, Graham L, Wang Y, Glimcher MJ. Density of organic matrix of native mineralized bone measured by water- and fat-suppressed proton projection MRI. Magn Reson Med. 2003;50:59-68.

30. Riemer F, Solanky BS, Stehning C, Clemence M, WheelerKingshott CA, Golay X. Sodium $\left({ }^{23} \mathrm{Na}\right)$ ultra-short echo time imaging in the human brain using a 3D-Cones trajectory. Magma. 2013. doi:10.1007/s10334-013-0395-2.

31. - Robson MD, Gatehouse PD, So PW, Bell JD, Bydder GM. Contrast enhancement of short T2 tissues using ultrashort TE (UTE) pulse sequences. Clin Radiol. 2004;59:720-6. This paper describes the principle of short T2 contrast enhancement using the subtraction technique.

32. Rahmer J, Blume U, Bornert P. Selective 3D ultrashort TE imaging: comparison of "dual-echo" acquisition and magnetization preparation for improving short-T2 contrast. Magma. 2007;20:83-92.

33. Carl M, Sanal HT, Diaz E, et al. Optimizing MR signal contrast of the temporomandibular joint disk. J Magn Reson Imaging. 2011;34:1458-64.

34. Du J, Chung C, Bydder G. Ultrashort TE Imaging with Rescaled Digital Subtraction (UTE RDS). In: Proceedings 17th Scientific Meeting, International Society for Magnetic Resonance in Medicine, Honolulu. 2009; 3992.

35. Lee YH, Kim S, Song HT, Kim I, Suh JS. Weighted subtraction in $3 \mathrm{D}$ ultrashort echo time (UTE) imaging for visualization of short T2 tissues of the knee. Acta Radiol. 2013. doi:10.1177/ 0284185113496994.

36. Techawiboonwong A, Song HK, Wehrli FW. In vivo MRI of submillisecond $\mathrm{T}(2)$ species with two-dimensional and threedimensional radial sequences and applications to the measurement of cortical bone water. NMR Biomed. 2008;21:59-70.

37. Sussman MS, Pauly JM, Wright GA. Design of practical T2selective RF excitation (TELEX) pulses. Magn Reson Med. 1998;40:890-9.

38. Larson PE, Conolly SM, Pauly JM, Nishimura DG. Using adiabatic inversion pulses for long-T2 suppression in ultrashort echo time (UTE) imaging. Magn Reson Med. 2007;58:952-61.

39. Du J, Takahashi AM, Bae WC, Chung CB, Bydder GM. Dual inversion recovery, ultrashort echo time (DIR UTE) imaging: creating high contrast for short-T(2) species. Magn Reson Med. 2010;63:447-55.

40. Moon SM, Yoder JH, Wright AC, Smith LJ, Vresilovic EJ, Elliott DM. Evaluation of intervertebral disc cartilaginous endplate structure using magnetic resonance imaging. Eur Spine J. 2013;22:1820-8.

41. Tyler DJ, Robson MD, Henkelman RM, Young IR, Bydder GM. Magnetic resonance imaging with ultrashort TE (UTE) PULSE sequences: technical considerations. J Magn Reson Imaging. 2007;25:279-89.

42. Du J, Takahashi AM, Chung CB. Ultrashort TE spectroscopic imaging (UTESI): application to the imaging of short T2 
relaxation tissues in the musculoskeletal system. J Magn Reson Imaging. 2009;29:412-21.

43. Williams A, Qian Y, Chu CR. UTE-T2* mapping of human articular cartilage in vivo: a repeatability assessment. Osteoarthr Cartil. 2011;19:84-8.

44. Du J, Carl M, Diaz E, et al. Ultrashort TE T1rho (UTE T1rho) imaging of the Achilles tendon and meniscus. Magn Reson Med. 2010;64:834-42.

45. Du J, Diaz E, Carl M, Bae W, Chung CB, Bydder GM. Ultrashort echo time imaging with bicomponent analysis. Magn Reson Med. 2012;67:645-9.

46. Qian Y, Williams AA, Chu CR, Boada FE. Multicomponent T2* mapping of knee cartilage: technical feasibility ex vivo. Magn Reson Med. 2010;64:1426-31.

47. Liu F, Chaudhary R, Hurley SA, et al. Rapid multicomponent T2 analysis of the articular cartilage of the human knee joint at 3.0T. J Magn Reson Imaging. 2013. doi:10.1002/jmri.24290.

48. Disler DG, McCauley TR, Wirth CR, Fuchs MD. Detection of knee hyaline cartilage defects using fat-suppressed three-dimensional spoiled gradient-echo MR imaging: comparison with standard MR imaging and correlation with arthroscopy. AJR Am J Roentgenol. 1995;165:377-82.

49. Hodler J, Resnick D. Current status of imaging of articular cartilage. Skeletal Radiol. 1996;25:703-9.

50. Recht MP, Piraino DW, Paletta GA, Schils JP, Belhobek GH. Accuracy of fat-suppressed three-dimensional spoiled gradientecho FLASH MR imaging in the detection of patellofemoral articular cartilage abnormalities. Radiology. 1996;198:209-12.

51. Chung CB, Boucher R, Resnick D. MR imaging of synovial disorders of the knee. Semin Musculoskelet Radiol. 2009;13:303-25.

52. Xia Y, Moody JB, Burton-Wurster N, Lust G. Quantitative in situ correlation between microscopic MRI and polarized light microscopy studies of articular cartilage. Osteoarthr Cartil. 2001;9:393-406.

53. Bydder M, Rahal A, Fullerton GD, Bydder GM. The magic angle effect: a source of artifact, determinant of image contrast, and technique for imaging. J Magn Reson Imaging. 2007;25:290-300.

54. - Bae WC, Dwek JR, Znamirowski R, et al. Ultrashort echo time MR imaging of osteochondral junction of the knee at $3 \mathrm{~T}$ : identification of anatomic structures contributing to signal intensity. Radiology 2010;254:837-45. This paper identified tissue components responsible for UTE MR morphology of osteochondral junction of the knee.

55. Bae WC, Chen PC, Chung CB, Masuda K, D'Lima D, Du J. Quantitative ultrashort echo time (UTE) MRI of human cortical bone: correlation with porosity and biomechanical properties. J Bone Miner Res. 2012;27:848-57.

56. Du J, Bae WC, Biswas R, et al. Ultrashort TE imaging and bicomponent analysis of the free and bound water in cortical bone and the correlation with $\mu \mathrm{CT}$ porosity. Radiol Soc North Am. 2011;97:SSG09-3.

57. Techawiboonwong A, Song HK, Leonard MB, Wehrli FW. Cortical bone water: in vivo quantification with ultrashort echotime MR imaging. Radiology. 2008;248:824-33.

58. Bae WC, Du J, Sinha S, et al. UTE MRI of deep layer of cadaveric patella at 3T: correspondence with calcified cartilage properties. In: BMES Annual Meeting. Los Angeles, CA, 2007.

59. Bae WC, Gupta N, Golnari P, Chang EY, Du J, Chung CB. Inside-out theory of cartilage degeneration: association of deep layer UTE morphologic alteration with quantitative MR properties of human articular cartilage. Radiol Soc North Am 2012; 98:SST08-5.

60. Koff MF, Shah P, Pownder S, et al. Correlation of meniscal T2* with multiphoton microscopy, and change of articular cartilage $\mathrm{T} 2$ in an ovine model of meniscal repair. Osteoarthr Cartil. 2013;21:1083-91.
61. Omoumi P, Bae WC, Du J, et al. Meniscal calcifications: morphologic and quantitative evaluation by using $2 \mathrm{D}$ inversion-recovery ultrashort echo time and 3D ultrashort echo time 3.0-T MR imaging techniques-feasibility study. Radiology. 2012;264:260-8.

62. Williams A, Qian Y, Golla S, Chu CR. UTE-T2* mapping detects sub-clinical meniscus injury after anterior cruciate ligament tear. Osteoarthr Cartil. 2012;20:486-94.

63. Robson MD, Benjamin M, Gishen P, Bydder GM. Magnetic resonance imaging of the Achilles tendon using ultrashort TE (UTE) pulse sequences. Clin Radiol. 2004;59:727-35.

64. Rad HS, Lam SC, Magland JF, et al. Quantifying cortical bone water in vivo by three-dimensional ultra-short echo-time MRI. NMR Biomed. 2011;24:855-64.

65. Pearce RH, Thompson JP, Bebault GM, Flak B. Magnetic resonance imaging reflects the chemical changes of aging degeneration in the human intervertebral disk. J Rheumatol Suppl. 1991;27:42-3.

66. Pfirrmann CW, Metzdorf A, Zanetti M, Hodler J, Boos N. Magnetic resonance classification of lumbar intervertebral disc degeneration. Spine. 2001;26:1873-8.

67. Forristall RM, Marsh HO, Pay NT. Magnetic resonance imaging and contrast $\mathrm{CT}$ of the lumbar spine: comparison of diagnostic methods and correlation with surgical findings. Spine (Phila $\mathrm{Pa}$ 1976). 1988;13:1049-54.

68. Hashimoto K, Akahori O, Kitano K, Nakajima K, Higashihara T, Kumasaka Y. Magnetic resonance imaging of lumbar disc herniation: comparison with myelography. Spine (Phila Pa 1976). 1990;15:1166-9.

69. Chatani K, Kusaka Y, Mifune T, Nishikawa H. Topographic differences of $1 \mathrm{H}-\mathrm{NMR}$ relaxation times $(\mathrm{T} 1, \mathrm{~T} 2)$ in the normal intervertebral disc and its relationship to water content. Spine (Phila Pa 1976). 1993;18:2271-5.

70. Kerttula L, Kurunlahti M, Jauhiainen J, Koivula A, Oikarinen J, Tervonen O. Apparent diffusion coefficients and T2 relaxation time measurements to evaluate disc degeneration: a quantitative MR study of young patients with previous vertebral fracture. Acta Radiol. 2001;42:585-91.

71. Benneker LM, Heini PF, Anderson SE, Alini M, Ito K. Correlation of radiographic and MRI parameters to morphological and biochemical assessment of intervertebral disc degeneration. Eur Spine J. 2005;14:27-35.

72. Marinelli NL, Haughton VM, Munoz A, Anderson PA. T2 relaxation times of intervertebral disc tissue correlated with water content and proteoglycan content. Spine (Phila Pa 1976). 2009;34:520-4.

73. Johannessen W, Auerbach JD, Wheaton AJ, et al. Assessment of human disc degeneration and proteoglycan content using T1rhoweighted magnetic resonance imaging. Spine. 2006;31:1253-7.

74. •• Bae WC, Statum S, Zhang Z, et al. Morphology of the cartilaginous endplates in human intervertebral disks with ultrashort echo time MR imaging. Radiology 2013;266:564-74. This paper identified tissue components responsible for the UTE MR morphology of the disco-vertebral junction of the spine.

75. Bae WC, Xu K, Inoue N, Bydder GM, Chung CB, Masuda K. Ultrashort time-to-echo MRI of human intervertebral disc endplate: association with endplate calcification. Proc Int Soc Magn Reson Med. 2010;18:3218.

76. Bae WC, Yoshikawa T, Hemmad AR, et al. Ultrashort time-toecho MRI of human intervertebral disc endplate: association with disc degeneration. Proc Int Soc Magn Reson Med. 2010;18:534.

77. Law T, Anthony MP, Chan Q, et al. Ultrashort time-to-echo MRI of the cartilaginous endplate: technique and association with intervertebral disc degeneration. J Med Imaging Radiat Oncol. 2013;57:427-34.

78. Geiger D, Bae WC, Statum S, Du J, Chung CB. Quantitative 3D ultrashort time-to-echo (UTE) MRI and micro-CT $(\mu \mathrm{CT})$ evaluation of the temporomandibular joint (TMJ) condylar morphology. Skeletal Radiol. 2013. doi:10.1007/s00256-013-1738-9. 
79. Li C, Magland JF, Rad HS, Song HK, Wehrli FW. Comparison of optimized soft-tissue suppression schemes for ultrashort echo time MRI. Magn Reson Med. 2012;68:680-9.

80. Goto H, Fujii M, Iwama Y, Aoyama N, Ohno Y, Sugimura K. Magnetic resonance imaging (MRI) of articular cartilage of the knee using ultrashort echo time (uTE) sequences with spiral acquisition. J Med Imaging Radiat Oncol. 2012;56:318-23.

81. Qian Y, Williams AA, Chu CR, Boada FE. High-resolution ultrashort echo time (UTE) imaging on human knee with AWSOS sequence at 3.0 T. J Magn Reson Imaging. 2012;35:204-10.

82. Idiyatullin D, Corum C, Moeller S, Prasad HS, Garwood M, Nixdorf DR. Dental magnetic resonance imaging: making the invisible visible. J Endod. 2011;37:745-52.

83. Wu Y, Hrovat MI, Ackerman JL, et al. Bone matrix imaged in vivo by water- and fat-suppressed proton projection MRI (WASPI) of animal and human subjects. J Magn Reson Imaging. 2010;31:954-63.
84. Du J, Takahashi AM, Bydder M, Chung CB, Bydder GM. Ultrashort TE imaging with off-resonance saturation contrast (UTEOSC). Magn Reson Med. 2009;62:527-31.

85. Hall-Craggs MA, Porter J, Gatehouse PD, Bydder GM. Ultrashort echo time (UTE) MRI of the spine in thalassaemia. Br J Radiol. 2004;77:104-10.

86. Gatehouse PD, He T, Puri BK, Thomas RD, Resnick D, Bydder GM. Contrast-enhanced MRI of the menisci of the knee using ultrashort echo time (UTE) pulse sequences: imaging of the red and white zones. Br J Radiol. 2004;77:641-7.

87. Du J, Carl M, Bae WC, et al. Dual inversion recovery ultrashort echo time (DIR-UTE) imaging and quantification of the zone of calcified cartilage (ZCC). Osteoarthr Cartil. 2013;21:77-85.

88. Sanal HT, Bae WC, Pauli C, et al. Magnetic resonance imaging of the temporomandibular joint disc: feasibility of novel quantitative magnetic resonance evaluation using histologic and biomechanical reference standards. J Orofac Pain. 2011;25:345-53. 